\title{
Constitutionally questioned: UK debates, international law and Northern Ireland
}

\author{
AoIfE O'DONOGHUE AND BEN T C WARWICK* \\ Durham Law School
}

\begin{abstract}
$\underline{\text { Abstract }}$
This comment examines the proposed UK constitutional changes proffered following the no vote in the Scottish independence referendum from an international legal perspective. With a particular focus on the implications for Northern Ireland, this piece considers the possible consequences of further devolution, proposed federalism, changes to the UK's relationship with the European Convention on Human Rights (ECHR), modifications of relations with the European Union (EU) and the potential effects of change to the relationship with the Republic of Ireland. In looking at these issues through the lens of international law, this comment brings a fresh perspective to questions of constitutional change for Northern Ireland.
\end{abstract}

Key words: constitutional change; devolution; federalism; self-determination; European Convention on Human Rights; border poll; European Union.

\section{Introduction}

$\mathrm{N}$ Torthern Ireland has been the catalyst for several UK constitutional upheavals. ${ }^{1}$ As the first region to achieve devolution in 1921, Northern Ireland established the UK prototype. Yet, one hundred years after the first set of Home Rule crises, the region is once again a fulcrum for the re-ordering of the UK's constitutional structures. ${ }^{2}$ While a referendum on Scottish independence provided political impetus for the current constitutional debates, in many ways Northern Ireland provides both a point of reference and of complication for constitutional analyses. Indeed, Northern Ireland's devolutionary experiences of disentangling competing interests provide ample basis for discussion. ${ }^{3}$ On the other hand, the particularities of the Northern Irish situation mean that proposed constitutional changes such as exiting the EU or the ECHR require special attention. The

* Our thanks to Kevin J Brown (Queen's University Belfast), C R G Murray (Newcastle University) and Se-shauna Wheatle (Durham University) for their advice and comments on earlier drafts. All errors remain our own.

1 For example, Northern Ireland hosted the first of the UK's devolved administrations and the UK Human Rights Act 1998 in part owes its existence to the Belfast Agreement 1998 (also known as the Good Friday Agreement) available at <www.gov.uk/government/publications/the-belfast-agreement> accessed 18 November 2014.

2 Government of Ireland Act 1920; Northern Ireland (Emergency Provisions) Act 1973; Alvin Jackson, Home Rule: An Irish History, 1800-2000 (OUP 2003).

3 Northern Ireland Constitution Act 1973; Northern Ireland Sovereignty Referendum 1973; Northern Ireland Act 1998. 
need for UK political, economic and legal actors to take account of historical experience as well as the implications of proposed changes for Northern Ireland should be more widely acknowledged. 4

Vast arrays of interconnected ${ }^{5}$ constitutional changes are being discussed and pressed forth, including: Scottish independence; ${ }^{6}$ increased powers for devolved governments; ${ }^{7}$ an English or regional assembly; ${ }^{8}$ a UK 'senate' chamber; 9 reformed relationships with human rights ${ }^{10}$ and with the EU. ${ }^{11}$ With such rapid and broad changes being proposed, a number of themes have, thus far, failed to attract the attention they require. For example, a variety of external and internal outcomes will influence and result from such constitutional change. If regarded from an international legal angle, we argue, greater clarity can be brought to the variety of outcomes that might result from constitutional disruption. It is this international legal, rather than purely domestic, perspective that this article takes in considering the variety of proposed changes.

First, this article will frame the need for international lawyers' analyses of the UK's constitutional debates. It will do so by highlighting the multitude of concealed agendas that currently dominate domestic politics, and which are driving various 'reform' agendas. The piece then moves on to examine some of the broader themes that underlie discussions on constitutional changes, such as the notions of self-determination, devolution and federalism. The international complications that Northern Ireland brings to current debates are then considered. Finally, the impact that these changes may have for the UK as a global actor is addressed. The general approach of the article is to contest the current misguided tendencies to define important constitutional changes by sole reference to internal factors. This tendency, it will be shown, neglects the significant external implications of 'internal' debates. Instead, the changes to the UK's constitutional settlement must, it is argued, be situated in the broader regional and international political and economic context. The exigencies of modern globalisation and commerce mean that external bodies and countries are both influenced by and influencers of 'internal' debates.

4 For example, the potential impacts of the the Conservative Party's naming of a 'British' Bill of Rights, <www.telegraph.co.uk/news/politics/conservative/11136146/A-British-Bill-of-Rights-should-bewelcomed.html $>$ accessed 18 November 2014.

5 For example, the threat of Scottish independence is clearly a factor in the offer of increased powers for devolved governments, which itself is clearly linked to debates about a new English assembly. An exit from the EU and the ECHR is more predominantly an English concern and such disjuncture between Scottish and English political identity undoubtedly influences debates on independence.

6 Fiona Hyslop (Cabinet Secretary for Culture and External Affairs), 'The Scottish Referendum, and the Prospects for Constitutional Reform', 30 October 2014 <http://news.scotland.gov.uk/SpeechesBriefings/The-Scottish-referendum-and-the-prospects-for-constitutional-reform-1216.aspx $>$ accessed 18 November 2014.

7 Secretary of State for Scotland, 'The Parties' Published Proposals on Further Devolution for Scotland', October 2014, Command Paper 8946.

8 Lord Wallace of Tankerness, 'Scotland: Devolution - Motion to Take Note', HL Deb, 29 October 2014, col 1293.

9 'Elected Senate Would Replace House of Lords under Labour', BBC News: Politics, 1 November 2014, <www.bbc.co.uk/news/uk-politics-29857849> accessed 18 November 2014.

10 'Protecting Human Rights in the UK: The Conservatives' Proposals for Changing Britain's Human Rights Law' <www.conservatives.com/ /media/Files/Downloadable\%20Files/HUMAN_RIGHTS.pdf> accessed 18 November 2014.

11 David Lidington MP, 'A Constructive Case for EU Reform', 13 December 2013, <www.gov.uk/government/speeches/a-constructive-case-for-eu-reform> accessed 18 November 2014. 


\section{Discussing change: don't judge a book by its cover}

Current constitutional ruminations have largely been shaped by a number of concealed agendas. Rather than defining constitutional debate by reference to the many international examples of power division, federal governance and devolution-type settlements, the UK's constitutional debate has been drawn on introverted constitutional debates. Each agenda represents different threats and opportunities for the regions. For instance, within England, the electoral fortunes of political parties lurk beneath the surface of proposed changes to voting within the Westminster Parliament. The removal or reduction of the voting powers of Scottish, Northern Irish and Welsh MPs is not only significant for the governance of the regions, but also has the potential to redraw the party political status quo. ${ }^{12}$ Although best known for arguing for independence from external entities such as the EU and the ECHR, the rise of the UK Independence Party (UKIP) has been significant in magnifying desires for internal autonomy and internal self-determination. ${ }^{13}$ For instance, on the "English votes for the English' question, the party has added pressure to mainstream political parties and shaped agendas. ${ }^{14}$ The recent swift decision by the UK government in concert with Greater Manchester Council's move to introduce a mayor for Manchester, despite voters in Manchester having rejected this in 2012, is a further example of this rush to change the current settlement. 15

In Scotland, a significant proportion of the concealed agendas belong(ed) to the markets. Dominant economic actors vocally campaign(ed) against independence on the basis that it would harm jobs and the prosperity of Scots. ${ }^{16}$ This was an important consideration for many, but, for the boards of directors and chief executive officers making the threats, ${ }^{17}$ it was not the primary motivation. Rather, in furthering the aims of their boards of directors and shareholders, the threat to the stability of markets and the broader business environment was the unspoken motivation for such a fight against Scottish independence.

Whilst in Northern Ireland the potential reopening of the settlement forged under the Good Friday Agreement is both a threat and a potential opportunity, much remains unsaid. There is fear of concealed and/or incremental changes that erode cultural identities, ${ }^{18}$ and

12 Puerto Rico serves as a useful example of representation without voting rights: Dorian Shaw, 'The Status of Puerto Rico Revisited: Does the Current US-Puerto Rico Relationship Uphold International Law' (1993) 17 Fordham International Law Journal 1006.

13 David Breed, 'Euroscepticism in Britain: Social Movement or Contentious Politics?’ (2013) 1 Praxis: Politics in Action 74, 82 and 86.

14 UKIP, although holding little formal power, has been significant in using soft power to shape policy and debate: ibid.

15 City of Manchester (Mayoral Referendum) Order 2012, 329/2012; Local Authorities (Mayoral Elections) (England and Wales) (Amendment) Regulations 2014, 370/2014; details at <www.gov.uk/government/uploads/system/uploads/attachment_data/file/369858/Greater_Manchester_A greement_i.pdf $>$ accessed 18 November 2014.

16 An illustration of the (financial) commitment to a no vote is visible in the list of corporate donors to the campaigning groups: Electoral Commission, 'Donations and Loans Received by Campaigners at the Referendum on Independence for Scotland (Pre-poll Reporting: 18 December 2013 to 26 June 2014)' (2014). <www.electoralcommission.org.uk/_data/assets/electoral_commission_pdf_file/0009/169425/2014-prepoll-donations-and-loans-2014-07-03-deadline.pdf> accessed 30 October 2014.

17 See e.g. RBS statement days before the Scottish referendum: 'Contingency Planning for Scottish Independence Referendum' <www.rbs.com/news/2014/09/statement-in-response-to-press-speculation-onre-domicile.html> accessed 18 November 2014.

18 A fear that is perhaps inherent in a power-sharing arrangement that allows for some, but not total, "cultural autonomy': Donald L Horowitz, 'Explaining the Northern Ireland Agreement: The Sources of an Unlikely Constitutional Consensus’ (2002) 32 British Journal of Political Science 193, 194. 
politics remains an ongoing battle between two sides conjoined in government with little substantial opposition. Besides the internal 'blockages'19 that these issues cause, there are also external implications. In particular, such internal paralysis has had repercussions for Northern Ireland's voice in debates on human rights, economic powers and the division of power in the UK. This is crucial, as a strong voice within the UK affects Northern Ireland's capacity to deal with the issues of austerity, social security, rural and urban poverty, policing and employment.

There is a danger that the questions of new constitutional settlements and the accompanying (re)division of power are determined without reference to these concealed agendas. This is likely to lead only to a transient solution to the multiple divergent desires within the UK. It also risks the concealed becoming overt in unpredictable ways. For example, the Conservative agenda for England might lead to cross-party stalemate and the stalling of progress for Scotland. For Scotland, it might be argued that various conspiracy theories and the growth of the \#the45 movement (a continuity movement demanding change on the basis of the 44.7 per cent of 'yes' voters) emerged due to the unease at apparent hidden influences. And for Northern Ireland, the stability of the current settlement is jeopardised.

\section{Underlying debates}

Self-determination is in vogue in the (still-)United Kingdom albeit within the UK-wide debate it is rarely expressly invoked. Self-determination sits at the heart of debates on the UK's relationship with the ECHR and the EU, Scottish independence, further devolution and border polls. The principle is widely recognised in international law and has roles in shaping both internal socio-political debates and in supporting claims for full independence. ${ }^{20}$ The self-determination principle is one that has been well tested in international law, having negotiated many difficult internal power-division and secession settlements. As such, it is a potent concept that has resonance for the UK's current precariousness. In particular, self-determination emphasises the importance of (geographic, social, political, economic) settlements that reflect the desires of the people. Put differently, to meet the demands of self-determination whatever settlement comes next for the various regions that comprise the UK, it must 'work' for each of them whether this is external (full independence) or internal (a spectrum of governance models within a state) in form.

Self-determination is the grant to a people of a right to determine their own governance mode (a finely balanced right within the UK). Federalism brings decision-making closer to individuals (a form of localism) and also moves each unit towards a position of equality. Yet devolution is more likely to take account of the needs of a particular geographical region and facilitates a clearer reproduction of the advantages of differing forms of governmental control. In asking settlement questions in terms of international self-determination (both external and internal), rather than in terms of historical reminiscences of nationhood or political manoeuvring, a more fruitful discussion may emerge. Considering Northern Ireland's experience of international legal settlements (the emergence of the Free State and the Good Friday Agreement between the UK and Ireland), it could provide leadership to the rest of the UK in this regard.

19 Statement by UK Prime Minister David Cameron, 'The Prime Minister David Cameron Made a Statement Ahead of Resumption of Talks at Stormont in Northern Ireland Today' <www.gov.uk/government/news/pm-statement-ahead-of-resumption-of-talks-in-northern-ireland> accessed 18 November 2014.

20 UN Charter, Article 1.2; Milena Sterio, The Right to Self-determination under International Law: 'Selfistans', Secession and the Rule of the Great Powers (Routledge 2013). 
The two predominant models - devolution and federalism - for the division of powers amongst either nations or geographical areas are often tied to the notion of internal selfdetermination. ${ }^{21}$ Devolution and federalism ${ }^{22}$ both have pluralist tendencies, ${ }^{23}$ whilst neither system is clearly or rigidly defined. ${ }^{24}$ While devolution is the current approach to the division of power in the $\mathrm{UK},{ }^{25}$ federalism offers an alternative political settlement that forms a responsive basis for many stable and successful states. The historical rationales for choosing (at least the terminology of) devolution over federalism is likely linked to the emergence of Home Rule for Ireland in the late nineteenth century. Those nineteenthcentury debates used federalism as a bargaining chip in a contentious negotiation, ${ }^{26}$ and thus a concept of devolution provided a less 'loaded' route for the Northern/Irish negotiations. Indeed, the fragmentation of the UK (from the Republic's choice of external self-determination to Northern Ireland's choice of internal self-determination) is an oftenneglected example within international law of how states achieve differing forms of governance autonomy. ${ }^{27}$ Current discussions give some scope for questioning this trust in devolution. ${ }^{28}$ Whilst a clear division between devolution and federalism is impossible, in general, federalism maintains the equal division of power amongst constituent units, holds governance at a particular level and maintains the same relationship between the centre and with each unit. Devolution reflects a diversity of arrangements and varies according to the strength of the downward governance push and the local needs of a population. This causes the relationship with the centre to vary as between units. As such, federalism oversees the relationship between specific points of governance, the constituent units of the federation are equivalent and held in a symmetric fashion. By contrast, devolution can include a cacophony of options and relationships with the centre.

Alongside the existing UK arrangements, this could include 'devolution' to cities such as London and Manchester or to new Northern English Assemblies as well as the existing units. $^{29}$ In both devolution and federalism, although power is not centralised, ${ }^{30}$ a central authority usually keeps control of defence and some, though not necessarily all, foreign

21 Christian Walter, Antje von Ungern-Sternberg and Kavus Abushov (eds), Self-determination and Secession in International Law (OUP 2014); John Loughlin, John Kincaid and Wilfried Swenden (eds), Routledge Handbook of Regionalism and Federalism (Routledge 2013).

22 Baron de Montesquieu, The Spirit of Laws (1748); Nicolaidis Kalypso and Robert Howse (eds), The Federal Vision: Legitimacy and Levels of Governance in the US and the EU (OUP 2001); Vernon Bogdanor, Devolution in the United Kingdom (OUP 2001).

23 Robert Schütze, 'Federalism as Constitutional Pluralism: Letter from America' in Mattej Avbelj and Jan Kommarek (eds), Constitutional Pluralism in the European Union and Beyond (Hart 2012) 185-212; Roderick Hills, 'Is Federalism Good for Localism: The Localist Case for Federal Regimes' (2005) 21 Journal of Law and Policy 187.

24 See e.g. Guy Peters, 'The United Kingdom becomes the Untied Kingdom? Is Federalism Imminent, or Even Possible?' (2001) 1 British Journal of Politics and International Relations. Bogdanor (n 22) defines the differences between federalism and devolution as the contrast between a system that divides rather than devolves power between parliaments.

25 One author notes that the UK's settlement has 'nothing in common with federalism': Archie Brown, 'Asymmetrical Devolution: The Scottish Case’ (1998) 69 Political Quarterly 215, 215.

26 See Bogdanor (n 22).

27 Norman Davies, Vanished Kingdoms: The History of Half-Forgotten Europe (Allen Lane 2012) 635.

28 Nicholas Mansergh, The Government of Northern Ireland: A Study in Devolution (Allen 1936).

29 Richard Moss, 'Back from the Dead? The New Northern Assembly Campaign' <www.bbc.co.uk/news/ukengland-16932030> accessed 18 November 2014.

30 Although devolution allows the centre to maintain an overall 'meta-control' of the arrangement itself, allowing unilateral alterations, while federalism requires renegotiation with the constituent parts. 
policy. ${ }^{31}$ Although a clear point of debate, this arrangement can provide the centre with the powers to alter and regulate relationships with external actors, such as the EU. For the UK, the extent to which the centre maintains the ability to reconfigure the relationships with devolved units without consultation remains an open debate. Pertinent are the statements of Arden LJ in Horvarth where she noted that UK devolution lacks the characteristics of federalism, in particular, the retention of parliamentary sovereignty enabling Westminster (subject to constitutional conventions) to restrict or revoke powers that it has given to the devolved administrations. ${ }^{32}$

The political and socio-economic divergences between units can also cause tensions to arise. The form of power-sharing that results from the creation of federated or devolved states can surface substantial regional biases and much debate has centred on the political solution for accommodating such differences. ${ }^{33}$ Prime examples in the federalism context are the differences between the US states of Louisiana and California or between the German states of Saxony and Bremen. Yet, the continued debates on the 'West Lothian question' and the significant socio-economic divergences between the UK's regions demonstrate that devolution can also lead to such tensions. Problems for national unity arise if such tensions lead to the pursuit of separation and the perception that to fulfil the requirements of self-determination total independence is necessary. The current proposals for constitutional change have done little to interrogate the choice of devolution over federalism and instead (out-dated) historical rationales have remained dominant.

\section{Not straightforward (for Northern Ireland): options for change}

\section{HUMAN RIGHTS REFORM AND GOODBYE GOOD FRIDAY}

At the Conservative Party conference in October 2014 there was a clearly voiced intention to introduce changes to the UK Human Rights Act 1998 (HRA) and to the relationship with the ECHR and the associated European Court of Human Rights. ${ }^{34}$ In particular, it was made clear that if changes to that relationship could not be successfully made, a majority Conservative government would withdraw from the ECHR. As has been noted elsewhere, this is a particularly pertinent issue for Northern Ireland. The Chief Commissioner of the Northern Ireland Human Rights Commission has addressed the prospect of change to the HRA noting that it is well crafted and both reflects and is embedded in our constitutional arrangements. ${ }^{35}$ The Good Friday Agreement places the introduction of the HRA as central to its settlement. ${ }^{36}$ Under the settlement the UK agreed to:

31 Gleider Hernández, 'Federated Entities in International Law: Disaggregating the Federal State?' in Duncan French (ed), Statehood and Self-Determination: Reconciling Tradition and Modernity in International Law (CUP 2013) 491-512.

$32 \mathrm{R}$ (Horvath) v Secretary of State for the Environment, Food and Rural Affairs [2007] EWCA Civ 620, [57].

33 Vernon Bogdanor, 'The West Lothian Question' (2010) 63 Parliamentary Affairs 156.

34 See 'Protecting Human Rights in the UK' (n 10).

35 Northern Ireland Human Rights Commission, 'Chief Commissioner Responds to Human Rights Act Proposals' 3 October 2014 <www.nihrc.org/news/detail/chief-commissioner-responds-to-human-rights-actproposals $>$ accessed 20 March 2015. The national human rights institution has also expressed concerns about the proposals: Equality and Human Rights Commission, 'Commission Warns against "Regressive" Change to Human Rights Laws' 20 March 2015 <www.equalityhumanrights.com/commission-warns-against$\%$ E2\%80\%98regressive \%E2\%80\%99-change-human-rights-laws> accessed 20 March 2015.

36 Aileen McHarg, 'Will Devolution Scupper Conservative Plans for a "British” Bill of Rights?', UK Human Rights Blog, 2 October 2014 <http://ukhumanrightsblog.com/2014/10/02/will-devolution-scupperconservative-plans-for-a-british-bill-of-rights $/>$. 
complete incorporation into Northern Ireland law of the European Convention on Human Rights (ECHR), with direct access to the courts, and remedies for breach of the Convention, including power for the courts to overrule Assembly legislation on grounds of inconsistency. ${ }^{37}$

The Irish government, in return, agreed to incorporate the ECHR into its law and passed legislation to this effect. ${ }^{38}$ Given that the Good Friday Agreement is partly a bilateral agreement between the UK and Ireland, the Conservative proposals would, if enacted, violate international law. ${ }^{39}$ Besides legality, courtesy would require the UK to consult with Ireland about such changes, perhaps with a view to releasing Ireland from its corresponding obligations. Of course, it might be the case that, as with Scotland, Northern Ireland could introduce an order that implements the ECHR for Northern Ireland alone. ${ }^{40}$ This solution, however, would miss the bilateralism of the Good Friday Agreement and, given the potential for suspension of Stormont, this would lead to a precarious situation for any human rights-based instrument. In either of these scenarios there would be a change to the current settlement. The Good Friday Agreement was put to a referendum in Northern Ireland and the Republic voted contemporaneously on changes to its constitutional settlement premised on the idea that the Good Friday Agreement would be fully implemented. As such, it seems democratically questionable to change its terms without consulting both constituencies again. ${ }^{41}$

Beyond the legal technicalities of the removal of ECHR protections for Northern Ireland, there would of course be practical differences. The emaciated version of human rights put forward in the Conservative proposals ${ }^{42}$ would do little to further the humanrights-based purposes of the Good Friday Agreement. An express safeguarding purpose of this element of the Good Friday Agreement was to allow 'the Courts to overrule Assembly legislation on grounds of inconsistency'. ${ }^{43}$ Notwithstanding the fact that domestic courts are not the Conservative's primary concern, this overruling power could be one of the incidental victims of the Conservative Party's reforms, which prioritise parliamentary intent and enactment over judicial intervention. ${ }^{44}$ Further, with 'equality and human rights concerns' as the centrepiece of the Good Friday Agreement, ${ }^{45}$ the language and principles of human rights purported to permit the desired plurality and tolerance. As such, in Northern Ireland, human rights protections are not only a check on governmental power, but also an informal check on the dominance of the 'other side'.

The external nuances of the UK's current constitutional soul-searching are further indicated in the potential ramifications of a Northern Irish 'border poll' to determine the 'constitutional position' of the province. While there has been much talk of a border poll

37 Belfast Agreement (n 1) 'Rights, Safeguards and Equality of Opportunity', para 2.

38 European Convention on Human Rights Act 2003; Fiona de Londras and Cliona Kelly, European Convention on Human Rights Act: Operation, Impact and Analysis (Roundhall/Thomson Reuters 2010).

39 UN Treaty Series, United Nations Treaty Series Cumulative Index vol 41 (2013). See also Northern Ireland Human Rights Commission (n 35).

40 Scotland Act 1998, s $100(1)$.

41 Peter F Trumbore, 'Public Opinion as a Domestic Constraint in International Negotiations: Two-Level Games in the Anglo-Irish Peace Process' (1998) 42 International Studies Quarterly 545.

42 See 'Protecting Human Rights in the UK' (n 10) 3.

43 Belfast Agreement (n 1) 'Rights, Safeguards and Equality of Opportunity'.

44 'Every judgement [sic] that UK law is incompatible with the Convention will be treated as advisory': see 'Protecting Human Rights in the UK' (n 10) 6.

45 Paul Mageean and Martin O’Brien, 'From the Margins to the Mainstream: Human Rights and the Good Friday Agreement' (1998-1999) 22 Fordham International Law Journal 1499, 1499. 
in Northern Ireland, this has largely neglected the voice of the Republic. ${ }^{46}$ The Good Friday Agreement mandated a right to self-determination for the people of the Republic in the following terms:
it is for the people of the island of Ireland alone, by agreement between the two parts respectively and without external impediment, to exercise their right of self-determination on the basis of consent, freely and concurrently given, North and South, to bring about a united Ireland, if that is their wish, accepting that this right must be achieved and exercised with and subject to the agreement and consent of a majority of the people of Northern Ireland. ${ }^{47}$

As such, self-determination for 'North and South' would mean that even if Northern Ireland voted for a unification of Ireland, there would be no certainty of a united Ireland. The terms of the Good Friday Agreement and the right to self-determination would seem to mandate (albeit not clearly) the Irish government to hold a referendum on the matter. Further, the exact form that any unification would take would need careful consideration. A united Ireland could mean an end to the unitary governmental system in Dublin and move the country, for example, towards a federal or devolved system between Northern Ireland and other potential (provincial) sub-units on the island. ${ }^{48}$

It is by no means certain that a vote in the Republic on the matter of unification would bring about a majority of yes voters. The reunification of Germany in 1990 provides an interesting parallel. No vote took place when East Germany rejoined West Germany for two reasons: firstly, because the German Constitution never gave up its claim to the entire geographic area; and, secondly, it was by no means certain that the West Germans would vote to integrate their East-German neighbours. On the first point, changes to Articles 2 and 3 of the Irish Constitution, replacing the Republic's 'all-island claim of sovereignty' with a lesser conferral of citizenship rights on those living on the island, makes the constitutional point less clear. Therefore, if a government sought constitutional change, only then would a vote be mandatory. ${ }^{49}$ However, most critically, like in West Germany, a yes vote in the Republic for unification is by no means certain.

The Good Friday Agreement requires that the exercise of self-determination is for the people of the island of Ireland alone. ${ }^{50}$ It is not clear if this means that politicians from England, Wales and Scotland would be prohibited from engaging in the political debate leading up to a referendum. The Irish government remained studiously silent on the question of Scottish independence but it would seem unusual if the rest of the UK were to remain without comment if a vote were to happen in Northern Ireland. ${ }^{51}$ Any such vote is likely, much like the Scottish vote, to gain some international comment. Both the Obama

46 Although it is true that there is not universal Northern Irish interest in a border poll. In particular, it is notable that of those who desired a border poll only 43.4\% were women; Liam Clarke, "Northern Ireland Says "Yes" to a Border Poll . . but a Firm "No" to United Ireland' Belfast Telegraph (Belfast 29 September 2014).

47 Belfast Agreement (n 1) Article 1(ii).

48 This is not a new idea and was a central argument of the Irish Centre Party before the partition of the island: Colin Reid, 'Stephen Gwynn and the Failure of Constitutional Nationalism in Ireland, 1919-1921' (2010) 53 Historical Journal 723. This proposal has been mooted by Sinn Féin: Gerry Adams TD, 'A New Exciting Future - Uniting Ireland' 19 November 2011 <www.sinnfein.ie/contents/20204> accessed 18 November 2014.

49 Nineteenth Amendment of the Constitution Act 1998; Bryan Fanning and Fidele Mutwarasibo, 'Nationals/Non-nationals: Immigration, Citizenship and Politics in the Republic of Ireland' (2007) 30(3) Ethnic and Racial Studies 439, 446.

50 Belfast Agreement (n 1) Article 1(ii).

51 Patrick Smyth, 'Irish Seem Lost for Words on Scottish Independence' Irish Times (Dublin 18 July 2014). 
administration $^{52}$ and José Manuel Barroso, President of the European Commission, commented on the potential of Scottish independence. ${ }^{53}$ In particular, they were vocal on what independence might mean for the dénouement of UK power.

\section{SELF-DETERMINATION?}

The particular implications of the Good Friday Agreement for the nature of selfdetermination fit within broader trends. The 'self' in self-determination has become less clearly defined in the face of international influences. The Scottish referendum evidenced a tendency for international leaders to pay lip-service to the right of the Scots to determine their own future, while mounting substantive, and in some cases bad faith, arguments for one or other result.

Further, the economic and taxation choices of Scotland and Northern Ireland continue not only to be a matter for the 'self' but are also the subjects of international influence. This influence commonly occurs through the vehicle of both positive and negative examples. Scotland and Northern Ireland have been warned of the 'dangers' of changes to their taxation regimes, through the examples of 'tax havens' such as Jersey. ${ }^{54}$ Likewise, those arguing in favour of a particular model of social democracy hold out (much-stereotyped) 'beacons' such as Norway, Luxembourg or Iceland.

In part, such arguments reflect the nature of modern global governance and, in part, they are reflective of the death of 'tax sovereignty'. ${ }^{5}$ A high number of active tax havens enable widespread avoidance of tax liability, ${ }^{56}$ and a global business environment can cause states to be outmanoeuvred by multinational corporations. As such, discussions of new constitutional settlements should consider the particular implications of such a globalised fiscal environment. Multilateralism and cooperation between (the constituent parts of) the UK and Ireland are essential if tax regimes are to be effective and efficient and are to avoid a 'race to the bottom'.

\section{BORDERING ON THE EU}

Of further consideration is the potential of the UK leaving the EU and its impact on Northern Ireland. ${ }^{57}$ The EU now comprises a complex web of overlapping legal entitlements and demands; these include the Charter of Fundamental Rights and the Schengen border agreement. At present, the Irish Republic and the UK are not part of the Schengen area (having secured an opt-out) ${ }^{58}$ and as such there is little problem with the

52 'Obama Backs "Strong and United" UK' BBC News, 5 June 2014 <www.bbc.co.uk/news/uk-scotlandscotland-politics-27713327> accessed 18 November 2014.

53 'Barroso: Scots EU Bid "Difficult" BBC News, 16 February 2014 <www.bbc.co.uk/news/uk-scotlandscotland-politics-26215963> accessed 18 November 2014.

54 “Tax haven” Warning over SNP Plans' Sunday Post (Dundee 27 August 2014).

55 Special Rapporteur on Extreme Poverty and Human Rights, 'Report of the Special Rapporteur on Extreme Poverty and Human Rights, Magdalena Sepúlveda Carmona (Fiscal Policy and Human Rights)' UN Doc A/HRC/26/28 2014.

56 Ronen Palen, Richard Murphy and Christian Chavagneux, Tax Havens: How Globalisation Really Workes (Cornell University Press 2013).

57 The Conservative Party position can be read at 'Let Britain Decide' <www.letbritaindecide.com> accessed 18 November 2014.

58 EU Treaty of Amsterdam 1997, 140-1. 
open status of the Ireland-UK border. ${ }^{59}$ Despite Liechtenstein, Iceland, Norway and Switzerland's status as non-EU countries that sit within the Schengen area, ${ }^{60}$ there would likely be practical difficulties for a UK that was outside of the EU. Although not as calamitous a scenario as was sometimes portrayed in relation to a potential England-Scotland border, ${ }^{61}$ should the UK leave the EU and Ireland then enter the Schengen area, ${ }^{62}$ it would undoubtedly make the open border between the two states more problematic. In particular, with a dominant aim of UK political actors being to stop inward migration, the border could not be as porous. Whilst the Irish are (legally) not to be treated by the UK as 'foreigners' under the Ireland Act 1949, other EU citizens entitled to continue to come to Ireland may pose practical and political difficulties for the UK. ${ }^{63}$ In addition, the entitlement of those born in Northern Ireland to dual citizenship of the UK and Ireland could cause practical problems. ${ }^{64}$ If an individual chose to register for an Irish passport, they would be able to maintain their EU citizenship even if the UK left the EU. This would be in stark contrast to other UK passport-holders in Scotland, England or Wales who would not retain the right to free movement of people, services or capital that those born in Northern Ireland would retain.

If, following a border poll, Northern Ireland chose to join the Republic, it is highly unlikely that this would impact upon either UK or Irish membership of the EU. However, for a Northern Ireland that remained in the UK, leaving the EU would impact upon the Transatlantic Trade and Investment Agreement currently being negotiated with the USA. 65 While there is not space here to discuss the many problematic elements of this trade deal, a UK that sat outside of the EU would be unable to benefit from this preferential trade agreement. Such a scenario would leave Northern Ireland without privileged access to US markets whilst the Republic would maintain its own access as part of the EU. Leaving the EU would also put the UK in an entirely different position within the World Trade Organisation (WTO). Notwithstanding the UK's individual membership of the WTO, all of its negotiations are currently conducted as part of one EU block. Therefore, while the UK would stay as a member of the WTO, it would negotiate as a standalone state rather than as part of the world's biggest market. It is unlikely that the UK would be able to leave the EU and continue with the trade agreements concluded by the EU within the WTO. Again, as the Republic would remain part of the EU's block in the WTO, it would maintain the many and varied benefits that the EU holds due to its global economic power. Whilst the EU's negotiations cannot always be said to be fair or equitable to developing states, from a domestic perspective, they do currently provide beneficial access for Northern Ireland. In the short and medium term, the loss of direct access to these markets on a preferential basis would be (economically) problematic for Northern Ireland. In particular, Northern Ireland

59 Agreement between the Governments of the States of the Benelux Economic Union, the Federal Republic of Germany and the French Republic on the Gradual Abolition of Checks at their Common Borders (agreed 14 June 1985).

60 For discussion, see Andrés Delgado Casteleiro, 'Relations between the European Union and Switzerland: A Laboratory for EU External Relations?’ in Francesco Maiani et al (eds), European Integration without EU Membership: Models, Experiences, Perspectives (European University Institute 2009) $108 \mathrm{ff}$.

61 Ben Riley-Smith, 'Britons "Would Need Passport to Visit an Independent Scotland" The Telegraph (14 March 2014).

62 Such an act by Ireland would also mean the end of the Common Travel Area with the UK that dates back to a 1923 agreement.

63 Ireland Act 1949, s 2(1).

64 Irish Nationality and Citizenship Act 2004, s 4.

65 European Commission, 'The Transatlantic Trade and Investment Partnership (TTIP): TTIP Explained' (8 May 2014). 
would have to compete with global farmers without the protection of the Common Agricultural Policy or the myriad other concessions that EU farmers have negotiated for themselves as a powerful customs union within the WTO. 66

\section{Constitutional manoeuvring: global positioning}

The proposed changes to human rights, bilateral agreements and the geographical/political makeup of the UK, all have potential to affect the UK's geopolitical power. The changes are likely to impact upon the state's soft and hard power. For example, a change in the UK's position within bodies such as the EU and WTO is likely to damage the soft power ${ }^{67}$ - or 'power over opinion' - of the UK and lead to damage to the 'inextricably linked' hard ('military and economic') power of the country. ${ }^{68}$ Indeed, for a clue to the external implications of a constitutionally/politically/economically changed UK, it is worth noting the political developments that unfolded contemporaneously to the Scottish independence referendum. That the UK parliamentary vote on military action in Iraq against Islamic State (Isis) was kept for the week after the Scottish referendum is perhaps indicative. ${ }^{69}$ So substantial would the political and global security ramifications of a break-up of the UK be that embarking on a military operation simultaneously would be difficult. From a geopolitical perspective, Northern Ireland separating is unlikely to be as momentous as Scotland leaving the UK. Yet it would, in the longer term, continue the trend of giving reason to question the UK's entitlement to statuses such as a permanent seat on the UN Security Council or its voting power at the International Monetary Fund or World Bank Group if it were to continue a drift toward further break-up. ${ }^{70}$

Leaving the Council of Europe (a clearly contemplated option in the Conservatives' proposals) could also damage the UK's global power. Human rights form a substantial part of UK foreign policy ${ }^{71}$ and membership of and adherence to the terms of the Council of Europe are likely to contribute to any respect or 'soft power' that the UK currently has. Similarly, the UK's international standing and its relationship with Ireland could suffer if the obligations under the Good Friday Agreement were not observed and consulted upon.

\section{Conclusion}

While wishes to 'reclaim' sovereignty often permeate these debates, whether the web of socio-economic, political and legal responsibilities and rights allows for 'reclaimed' sovereignty is highly questionable. A Northern Ireland that remains in a UK that leaves both the ECHR and the EU is unlikely, like the other devolved entities, to gain significant

66 European Commission, 'The Common Agricultural Policy after 2013' (29 August 2014).

67 Maria Gritsch, 'The Nation-state and Economic Globalization: Soft Geo-politics and Increased State Autonomy?' (2005) 12 Review of International Political Economy 1, 9. This applies mutatis mutandis in respect of human rights: Louise de Sousa, 'Women and Democracy', 9 March 2013, Lecture at Nottingham Annual

Human Rights Conference <www.nottingham.ac.uk/hrlc/events/annualstudentconference/pastconferences/2013.aspx> accessed 18 November 2014; 'Farmer's Relief at EU Deal' Belfast Telegraph (Belfast 27 June 2014).

68 Jan Melissen, Wielding Soft Power: The New Public Diplomacy (Netherlands Institute of International Relations 2005) 2.

69 As, perhaps, is the invocation of geographical comparisons between the (then) size of the Isis caliphate and the combined size of Scotland, England and Wales: Jim Wells MP, 'Persecution of Christians in Iraq and Syria: Private Members’ Business’ 23 September 2014, Official Report of the Northern Ireland Assembly 97(6).

70 On this prospect, see Nigel D White, 'The UK's Membership of the UN in the Event of Scottish Independence' (2012) Nottingham Working Paper <http://eprints.nottingham.ac.uk/1957/> accessed 18 November 2014.

71 See e.g. UK Foreign and Commonwealth Office, 'Human Rights and Democracy: The 2011 Foreign and Commonwealth Office Report' (April 2012). 
autonomy from this step alone. The same global forces which were so evident in the recent global financial and economic crises, and which exist presently with regard to ISIS, will still be there, and the ability to act independently of any outside influence will be just as difficult. Indeed, if further devolution takes place to allow the province to take control of its tax system, the same can be argued. Even other options - such as joining the Republic - are unlikely to bring complete freedom from global forces. The ability to shift fiscal policy or lower the corporate tax rate remains highly dependent on what other states are doing and the state of the global economy. Whether being subject to such free market capitalist trends is good or ill is almost beside the point. Self-determination in the modern era is not synonymous with political claims of sovereignty or full political and legal authority. Rather than attempting to (re)gain 'control' by evading global forces, political actors in the UK might better achieve their aims through accepting the existence of the global environment and contesting tenets of it. Further, there is an urgent need to take account of Northern Ireland; both in terms of the historical insights it can offer, as well as the implications of proposed changes. The current inward-looking approach to constitutional reform that does not account for the myriad of implications of an exit from various bodies is unlikely to result in a strong economic or political position for the UK or its devolved units. Rather, it will lead to an (even more) fragmented country, no better protected against the buffeting of international forces and without the redeeming virtue of furthering substantive internal self-determination. 